\title{
The Determinants of Deviant Workplace Behavior of Faculty Members working in Public Sector Universities of Punjab, Pakistan
}

\author{
${ }^{a}$ Muhammad Farooq Rehan, ${ }^{\text {b }}$ Raheel Mumtaz, ${ }^{\mathrm{c}}$ Quaisar Ijaz Khan \\ ${ }^{a}$ Assistant Professor Government College University Faisalabad, Pakistan \\ ${ }^{\mathrm{b}}$ Assistant Professor Government College University Faisalabad, Pakistan \\ Email: raheelmumtaz@gcuf.edu.pk \\ ${ }^{\mathrm{c}}$ Assistant Professor Government College University Faisalabad, Pakistan
}

\begin{tabular}{ll}
\hline ARTICLE DETAILS & ABSTRACT \\
\hline History: & The aim of the research is to empirical evaluate the effect of \\
Accepted 28 October 2021 & organizational formal control and workgroup norms on the deviant \\
Available Online December 2021 & $\begin{array}{l}\text { workplace behavior of the university faculty members of Pakistan. It } \\
\text { further investigates the moderating effect of self-regularity efficacy. The }\end{array}$ \\
\hline Keywords: & study is primary in nature and used survey method to collect the \\
Determinants, Workplace & responses from the teaching faculty of Pakistan. A total of 168 suitable \\
Behavior, Public Sector & responses were analyzed by using SMART PLS version 3 (Licensed). A \\
Universities & PLS-SEM was used for analysis of the collected data. The result showed \\
& that when employees find themselves in under the influence of reference \\
JEL Classification: & others, self-regulatory efficacy help them to attain compliance with \\
J23, J29 & significant organizational norms and doing that keep them away from \\
& involving in deviant workplace behaviors. Additionally, the results \\
suggest that self-regularity efficacy have a significant part in regulating \\
behaviors and observance to right self-sanctions for flawed \\
behavior.
\end{tabular}

(C) 2021 The authors. Published by SPCRD Global Publishing. This is an open access article under the Creative Commons AttributionNonCommercial 4.0

Corresponding author's email address: raheelmumtaz@gcuf.edu.pk

\section{Introduction}

Deviant workplace behaviors (DWB) was explained as a intentional conduct that disturbs substantial organizational norms and so intimidates the well-being of an organization, its employees, or as whole (Kura, Faridahwati, \& Chauhan, 2014). These activities may comprise of coming to organization too late or leave the organization before time without any approval from the management, intentionally avoid all the instructions by supervisor, dishonesty or cheating and robbery at the workplace. Researchers have theorized and characterized these behaviors in different forms like counterproductive behavior, bad behavior in organizations, anti- citizenship behavior, aggressive behavior antisocial behavior retaliation in the workplace, cyber loafing and dysfunctional behavior (Kura et al., 2014).

Deviant workplace behavior is a prevailing and expensive occurrence for organizations (Ahad, 
Mustafa, Mohamad, Abdullah, \& Nordin, 2021). Different studies concluded that deviant workplace behavior not only cost an extensive amount of money annually to the organizations, also they have psychological and negative concerns for employees as well (Carre, Mueller, Schleicher, \& Jones, 2017; Chang, Chou, \& Han, 2018). For instance, Mohamed, Zeinhom, Higazee, \& Goda, (2018) reported that employee theft was attributed to about $45 \%$ of the United States retailers' inventory shortage in 2010. A recent study of the Conference Board of Canada also estimated that due to absence from workplace Canadian economy have lost $\$ 16.6$ billion In 2012, which is one of the forms of deviant behavior at work (Harisur, Howladar, Rahman, \& Uddin, 2018). Employee deviance have negatively relationship with both customer satisfaction and corporate profitability (Mehar, Asif, \& Hassan, 2018).

Regarding the negative consequences of DWBs to employees, research indicates that targets of interpersonal deviance (DWBI), such as harassing and bullying were found to report lower levels of organizational commitment (Shabbir et al., 2014). However, lower levels of self-confidence increased absenteeism, quitting work or intention to quit, and Counterproductive work behavior resulted as increase on-the-job drug use/abuse, among others (Quddus et al., 2020).

Recently, in Pakistan, cases of deviant workplace behavior, include bribery at workplace, and caricature at work had been reported in international and national media. As per the survey started by the Centre for Law Enforcement Education cases of the corruption and bribery was increase in Pakistani Government (Nelofer, 2013; Saher, Bibi, Farmanullah, \& Abbas, 2014).

Additionally, the outcome of a survey revealed that almost one out of every four respondents, representing nearly 24 percent affirmed that they were being asked to give kickback by Govt. executives including polices, tax officials, court affairs, and anti- corruption agency before services could be served to them. Prior research has demonstrated that workplace deviance like bribery and corruption may reason of serious damage to an organization's reputation. Hence, it may prevent the organization from generating future profits (Ali, Khan, Ghazi, Shahzad, \& Khan, 2010; Dwyer, Mesak, \& Hsu, 2005; Kura, 2014).

Furthermore, to narrow it down to the Pakistan higher education institutions, workplace deviance such as absenteeism of some faculty member from classes, academic plagiarism, unconstitutional reward of number depends on purchase of handouts and exchange of currency for numbers have also been frequently stated in the news (Côté, Lauzier, \& Stinglhamber, 2021; A. Iqbal, Rehman, Ali, Khan, \& Khan, 2014). In general, unfavorable work environment as reflected by injustice in the workplace, lack of organizational support, break of psychological agreement and poor leadership, for instance, play a significant role in influencing deviant workplace behaviors (Baltaru, 2019; Rabiul \& Yean, 2021).

Past literature discovered that a group norms have relationship with organizational citizenship behavior and organizational performance Quaisar, Shukor and Soffian (2015), among others. Although work group norms are theoretically important in understanding job performance, however little work has still been done on the role of work group norms in explaining deviant workplace behavior, with some exceptions of the works of Dabney (1995) and Bamberger and Biron (2007). The present study is significantly different from these two studies because the later mainly focused on specific forms of deviant behavior at work (i.e., drug diversion and employee absenteeism, respectively). Hence, further studies are needed to incorporate a broader form of workplace deviant behavior construct (Robinson \& Bennett, 1995). However, there has been a lack of studies on the use of certain situation-specific measures of deviant workplace behavior. 
Additionally, despite of several studies that have examined different factors that effects individuals to engage in workplace deviant behaviors. Hence, workplace deviant behavior asks for more research in Pakistan because the results of the earlier research might not be generalizable for the Pakistan context because of having different contextual and cultural values. Since the focus on following research was to observe the effect of control systems on deviant workplace behavior among teaching staff in Pakistan's universities, individuals were the items of analysis in this current study. Hence, the existing study searches for the following research questions:

1. Does organizational formal control have deviant workplace behavior?

2. Does perceived group norms have deviant workplace behavior?

3. Does self-regularity efficacy moderate the relationship between deviant workplace behavior and organizational formal control?

4. Does self-regularity efficacy moderate the relationship between deviant workplace behavior and perceived group norms?

\section{Literature review and hypotheses development}

This section describes the basic concepts of deviant workplace behavior, formal organizational control, perceived group norms and self-regularity efficacy. Consequently, the relationship among variables as well as moderator explains by the research model and hypotheses.

\subsection{Workplace Deviant Behavior}

Deviant workplace behavior gives a comprehensive framework which can be useful for various subsequent studies. The workplace deviance consists of two basic types: organizational and interpersonal deviance (Quaisar, Shukor, \& Soffian, 2015; Robinson \& Bennett, 1995). Organizational deviance explains the acts like robbery or damage of a company's assets and behavior like refusal to work or to fulfill the tasks on given deadlines. Interpersonal deviance includes blaming other employees without any reason, or verbally or physically abusing a colleague. Factors relating to employee deviance includes absenteeism, withholding efforts and high turnover (Quaisar, Shukor, \& Soffian, 2016b, 2016a). whilst, (Robinson \& Bennett, 1995) define deviant behaviors into a single framework, many studies explain the reasons of such behaviors and define their importance comparative to other factors.

Although from few years now the deviant behavior concept has grown rapidly, literatures show the absence of arrangement about the terminology designed, but also the definition presented of what is measured to be a comparable construct(Adeoti, Shamsudin, \& Wan, 2017; Al-Shuaibi, Subramaniam, \& Shamsudin, 2014; Farida, Ardyan, \& Nuryakin, 2016). For example, many researchers offer different names to the deviant behavior such as "dysfunctional behavior", "organizational misbehavior", "counterproductive work behavior", "non-complaint behavior" and among others.

Specifically, research indicate workplace deviance behavior is linked with a huge variation of negative consequences, like lower level of confidence, decreased organizational commitment, increased absenteeism, increased on- the- job drug use/abuse, and actual turnover or turnover intention, among others (Mehar et al., 2018; Sang, Xuan, Ismail, Siti, \& Tan, 2014).

\subsection{Antecedents of Workplace Deviance}

Workplace deviant behavior antecedents can be divided into four types: organizational factors, individual factors, job factor and group factors (Murphy, 2017; Stewart, Bing, Davison, Woehr, \& Mcintyre, 2014; Tuna et al., 2016). Organizational factors are situational factors such as trust, justice, politics and culture that influence individual to involve in deviant behavior at work (Robinson \& 
Bennett, 1995; Sunday, 2013). Individual factors refers to factors which includes personality characteristics, demographic features (like age, education, gender, marital status, income level), attitudes, emotions and values that influence employees to involve in workplace deviance (Ramzy, Bedawy, \& Maher, 2018).Job factors which are associated with the job like satisfaction from job, job stress and job security among others.

\subsection{Organizational Formal Control}

Organizational formal control explains from three different viewpoints, which included: human resource management viewpoint, marketing viewpoint, accounting viewpoint. As from human resource management viewpoint, organizational formal control defines as "procedural and physical objects at the workplace which is specially designed to decrease the existence of events that detrimental to organization". Next from the accounting perspective, as we define organizational formal control "these managerial strategies used to safeguard the decisions and behaviors of the employees within organization also reliable for the organization policies and objectives”. Taking the marketing viewpoint, organizational formal control has been explained by (Guan, Zhou, Ye, Jiang, \& Zhou, 2015) as "efforts by whole management or shareholders of the organizations to effect the behaviors and actions related to marketing workforces which gain wanted results". While organizational formal control from marketing and accounting perspectives are similarly important, yet this present study assumes human resource management perspective as operational definition for this work focuses on human resource management practices.

Present study adopts the typology of management control explain by for different reasons. Firstly, this typology of management control is applicable in marketing filed as well as other related fields particularly, human resource management. Secondly, this is sufficient for various management control practices (Fox, Spector, Goh, Bruursema, \& Kessler, 2012; Kumi, 2013; Saeed et al., 2014).

Empirical studies for the relationship among organizational formal control and deviant behavior is limited. Specifically, few studies focus on a single item of formal control as the predictor of workplace deviant behaviors, while some other studies focus on multiple items of formal control as the antecedents of workplace deviant behaviors (Fagbohungbe, Akinbode, \& Ayodeji, 2012; Nasurdin, Ahmad, \& Razalli, 2014; Spector \& Fox, 2010). Therefore, we hypothesis that

H1: Organizational formal control has positively significant relationship with deviant workplace behavior.

\subsection{Perceived Group Norms}

Each group have some norms like habits, some conventions, customs or expectations that regulate the member's behavior (Barhight et al., 2015). A group norm is define as standard and offensive behavior of a group (Carcioppolo et al., 2016). It indicates that workgroup norms perform survival and regulatory roles; they have strong influence on employee behavior by these reasons (Dickie et al., 2017).

Empirical studies and theoretical discussions claim that injunctive norms and descriptive norms that perceived are two dimensions of perceived group norms (Carre et al., 2017; Golparvar, 2015; Harisur et al., 2018). Injunctive norms explains the type of behaviors that many members of the group approve or reject (Khattak, Khan, Fatima, Zul, \& Shah, 2018; Tuna et al., 2016; Wang, Chen, \& Li, 2018). Descriptive norms define as behavior that majority group members perform in certain situation irrespective of its relevance (Fox, Spector, \& Miles, 2001; Spector, 2010). 
Past literature showed mixed results while explaining the relationship between group norms and deviant workplace behavior. For the better understanding of this relationship further studies are needed. While predicting the relationship between these two Falomir-pichastor et al., (2015) claimed that group norm considerably anticipated substance use/abuse by teenagers. Thus, the current research study hypothesis that

H2: Perceived group norms have relationship with deviant workplace behavior.

\subsection{Self regularity Efficacy}

Self-regularity efficacy explains that employee belief in their skills to regulate and control feelings, thoughts, motivation and behavior for the achievement of goals (Bandura, 1993, 1999; Zimmerman, Bandura, Martinez-pons, \& Martinez-pons, 1992). Self-regularity efficacy is considered as a situation-specific construct as well as cognitive resource that differ among individuals. Specifically, according to Bandura, (1999) people who regard themselves as highly effective act, feel and think differently from those who perceive themselves as ineffective. They produce their own future, rather than simply forecast it (Zimmerman, Bandura, \& Martinez-Pons, 1992).

The individuals who have greater level of self-regularity efficacy, few of these involve in behavior that avoid significance of organizational norms with lower sense of self regularity efficacy. These empirical studies explaining variety of individual's behavior on part of self-regularity efficacy, on the other hand, only some studies have been started to investigate the self-regularity efficacy with moderation effect on the relationships among behavioral outcomes and their predictors (Noe, Tews, \& Marand, 2013; Quaisar, Khulida, \& Tan, 2014; Quaisar et al., 2015).

In this study, self-regularity efficacy treated as moderation to see if this construct shows a significant part in explaining the negative effect of organizational formal controls on workplace deviance as well as decreasing the positive influence of perceived group norms on DWBs. This is for observing self-efficacy as moderation could rises researchers' theoretical acceptance and offer them with experimental evidence on how self-efficacy might be a potential moderation. Therefore, we hypothesis that;

H3: Self regularity efficacy has positively significant relationship with deviant workplace behavior.

H4: Self regularity efficacy didn't moderate the relationship between organizational formal control and deviant workplace behavior.

H5: Self-regulatory efficacy moderates the relationship between perceived group norms and deviant workplace behavior.

\section{Conceptual Framework Model}

A theoretical framework of the present study was developing to enlightening that role of selfregularity efficacy as moderator variable on (a) perceived formal controls-DWBs relationship; (b) workgroup norms deviant workplace behavior relationship. So two dimensions of workplace deviance which is, organizational deviance and interpersonal deviance are the dependent variables of this study. The independent variables are organizational formal control and perceived group norms, with each having two dimensions: perceived descriptive norms/injunctive norms and perceived behavior control/perceived outcome control, respectively. Moreover, the following study proposes self-regularity efficacy as a likely moderator variable on the association among organizational formal controls, workgroup norms and also deviant behavior at working place.

The defending role of self-regularity efficacy on perceived formal controls and deviant workplace behavior relationship, as well as workgroup norms and deviant workplace behavior relationship can be 
examined from different perspectives. Therefore, self-efficacy theory, social learning theory, and organizational control theory are used as underpinning theories in order to explain the above research framework.

\section{Methodology}

The basic aim of following study is to test a hypothesized structural model. The model theorized the self-regularity efficacy has a positive moderation effect for the relationships among organizational formal controls, workgroup norms and deviant workplace behavior. Based upon the developed research model, the study emphases on verification and testing of theory instead than developing the new one, thus, this study used the deductive research approach. The current research work adopts quantitative work approach to evaluate the structural relationship between the four constructs. The resource limitations of the researchers in relation of time and money and Cross-sectional research design used instead of longitudinal research design. As the selected population of this study was individual lecturers who are teaching in the selected Pakistani universities, for this study the items of analysis were individuals.

\subsection{Measurement of the constructs and instrument}

The current study used questionnaire as data collection instrument and questionnaires were distributed to the teaching faculty of the Pakistani universities. The questionnaire comprises of seven segments. Section one consists of 26 items that measure workplace deviance. Section two consists of nine items that measure self-regularity efficacy scale. Section three contains of three items that measures perceived descriptive norms. Section four also contains of three items that measures perceived injunctive norms. Section five comprises nine items that measure perceived behavior control. Section six contains five item that measures perceived outcomes control, while section seven comprises of five demographic variables including gender, age, rank, job tenure and highest educational qualification.

In current study, deviant workplace behavior is measured 10 items taken from Bennett \& Robinson, (2000) Two items taken from the Bennett \& Robinson, (2000) workplace deviance scales were dropped intended for this study as they were believe to be inappropriate to university teaching faculty of Pakistan. These six items were obtained based on preliminary telephone interviews with the head of departments, deans of the faculty and job incumbents. PLS path modeling was used to validate the six relevant items included in the measures of DWB.

To measure organizational formal control, 6 items were adapted from (Babakus, Cravens, Grant, Ingram, \& Laforge, 1996) and (Oliver, Anderson, Oliver, \& Anderson, 2015) organizational formal control scale, while the remaining seven items were adapted from management control scale. These two scales will measure two empirically derived dimensions of organizational formal control in the workplace: outcome- based control and behavior-based control. Organizational formal control scale was adapted from management control scale. Beside this study, (Oliver et al., 2015)organizational formal control scales used successfully in various empirical studies (e.g., Ahearne, Rapp, Hughes, \& Jindal, 2010; Küster \& Canales, 2011; Panagopoulos \& Dimitriadis, 2009; Piercy, Cravens, Lane, \& Vorhies, 2006; Slater \& Olson, 2000; Theodosiou \& Katsikea, 2007).

In current research, six items in the Opinions about Perceived Norms Scale developed by Bandura (1990) were used to observe the magnitudes of perceived group norms: perceived injunctive norms and perceived descriptive norms. Nine items were adapted from Bandura (1990) Self regularity 
Efficacy Scale to test self-regularity efficacy. Self-regularity efficacy was using a five Likert scale ranged from 1-5 (strongly disagree to strongly agree).

\subsection{Data Collection Method}

In present study, over-all of 300 questionnaires were spread to the academics in the public universities located in Pakistan. A total of 184 responses were retrieved out of those 300 , and this study found that 168 questionnaires were fit for the analysis the other 16 questionnaires are not valid for the analysis because these are not filled properly some of them are double filled and blank. This yielded a response rate is $61.3 \%$ which is suitable for the analysis with Smart PLS 3.2.8.

\section{Result and Findings}

The Reliability and Validity of constructs can be confirmed by checking the values of Cronbach's Alpha, rho_Alpha, Composite Reliability and Average Variance Extracted (AVE). The table 1 clearly shows that all these scale values of Cronbach's Alpha is greater than 0.70 , the values of composite reliability are more than 0.70 and the values of AVE are more than 0.5 which means that the data is reliable and valid and can be used for further analysis. Moreover, table 2 depict that the square root of AVE of each construct is greater than the correlation of the constructs, the results confirm the discriminant validity.

TABLE: 1 CONSTRUCT RELIABILITY AND VALIDITY:

\begin{tabular}{|l|l|l|l|l|}
\hline & Cronbach's Alpha & rho_A & Composite Reliability & $\begin{array}{l}\text { Average } \\
\text { Extracted (AVE) }\end{array}$ \\
\hline DWB & 0.930 & 0.934 & 0.941 & 0.615 \\
\hline OFC & 0.859 & 0.871 & 0.894 & 0.587 \\
\hline PGN & 0.912 & 0.913 & 0.932 & 0.695 \\
\hline SRE & 0.917 & 0.928 & 0.932 & 0.608 \\
\hline
\end{tabular}

Source: Smart PLS 3.2.8

TABLE: 2 DISCRIMINANT VALIDITY FORNELL-LARCKER CRITERION

\begin{tabular}{|l|l|l|l|l|}
\hline & DWB & OFC & PGN & SRE \\
\hline DWB & $\mathbf{. 7 8 4}$ & & & \\
\hline OFC & .611 & $\mathbf{0 . 7 6 6}$ & & \\
\hline PGN & 0.547 & 0.633 & $\mathbf{0 . 8 3 3}$ & \\
\hline SRE & 0.644 & 0.756 & 0.775 & $\mathbf{0 . 7 8 0}$ \\
\hline
\end{tabular}

Source: Smart PLS 3.2.8

After checking the validity and reliability of the constructs, the collected data was analyzed by using 10\% level of significance. The hypotheses of the study will be accepted if $\mathrm{P}$ value will be less than o.10 and T-statistics is greater than 1.64 . 
Figure 2

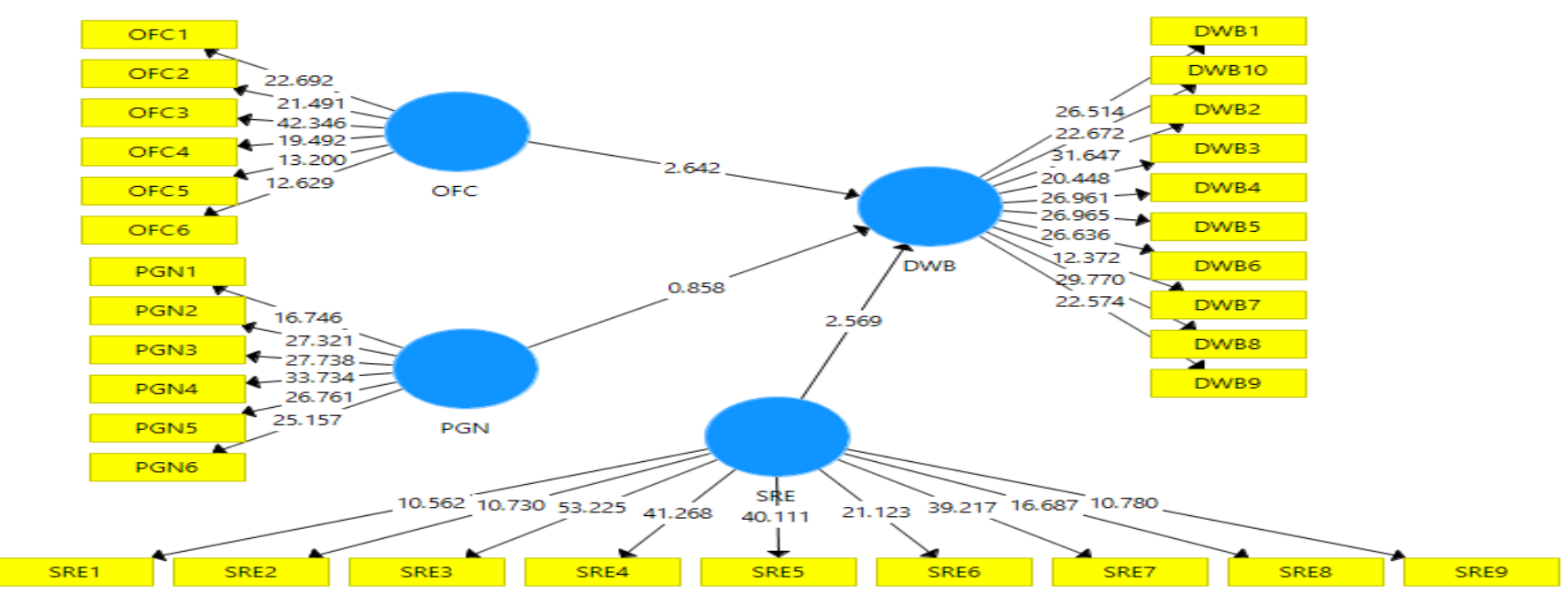

PATH COEFFicients:

Table 3 Mean, STDEV, T-Values, P-Values

\begin{tabular}{|l|l|l|l|l|l|}
\hline & $\begin{array}{l}\text { Original Sample } \\
\text { (O) }\end{array}$ & $\begin{array}{l}\text { Sample } \\
\text { Mean (M) }\end{array}$ & $\begin{array}{l}\text { Standard } \\
\text { Deviation } \\
(\text { STDEV })\end{array}$ & $\begin{array}{l}\text { T Statistics } \\
(\mid \mathbf{O} / \text { STDEV } \mid)\end{array}$ & Palues \\
\hline OFC -> DWB & 0.279 & 0.294 & 0.106 & 2.642 & $\mathbf{0 . 0 0 8}$ \\
\hline PGN -> DWB & 0.087 & 0.085 & 0.102 & 0.858 & $\mathbf{0 . 3 9 1}$ \\
\hline SRE -> DWB & 0.365 & 0.361 & 0.142 & 2.569 & $\mathbf{0 . 0 1 0}$ \\
\hline
\end{tabular}

Source: Smart PLS 3.2.8

Organizational formal control (Independent variable) to Deviant workplace behavior (Dependent variable) the table 4 shows the T-Statistics 2.592 which is higher than 1.64 and $\mathrm{P}$ value 0.010 which is less than 0.10 so this study found that the organizational formal control has a positively significant relationship with deviant workplace behavior.

Perceived group norms (Independent variable) to deviant workplace behavior (Dependent variable) the table 4 shows the T-Statistics 1.126 which is less than 1.64 and $\mathrm{P}$ value 0.260 which is higher than 0.10 so this study found that the perceived group norms have a no relationship with deviant workplace behavior.

Self- regulatory efficacy (Independent variable) to deviant workplace behavior (Dependent variable) the table 4 shows the T-Statistics 2.402 which is higher than 1.64 and $\mathrm{P}$ value 0.016 which is less than 0.10 so this study found that the self-regularity efficacy has a positively significant relationship with deviant workplace.

The self-regularity efficacy Moderates the association among organizational formal control (Independent variable) to deviant workplace behavior (Dependent variable) the table 4 shows the TStatistics 0.254 which is less than 1.64 and $\mathrm{P}$ value 0.800 which is higher than 0.10 so this study found that the self-regularity efficacy didn't have moderating effect on relationship among organizational formal control and deviant workplace behavior.

Secondly, the self-regularity efficacy Moderates the association among perceived group norms 
(Independent variable) to deviant workplace behavior (Dependent variable) the table 4 shows the TStatistics 0.1.666 which is significant at 10\% level of significant. So, this study found that the relationship between deviant workplace behavior of university teaching staff and perceived group norms is moderated by self-regularity efficacy.

FIGURE 3 HYPOTHESIS TESTING WITH BOOSTTRAPING:

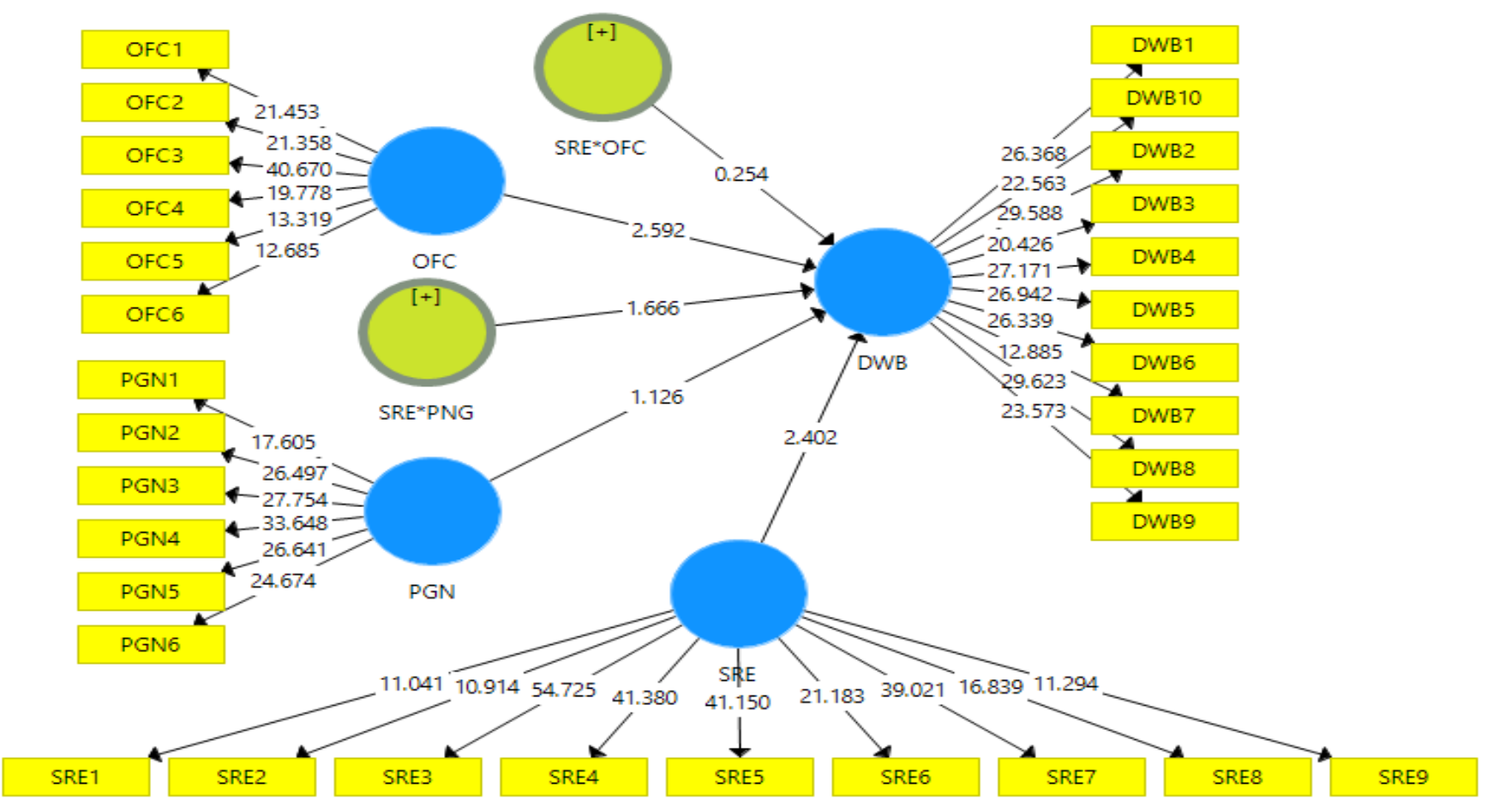

Source: $\quad$ Smart PLS 3.2.8

Table $4 \quad$ Path Coefficients with Bootstrap

Mean, STDEV, T-Values, P-Values

\begin{tabular}{|l|l|l|l|l|l|}
\hline & $\begin{array}{l}\text { Original } \\
\text { Sample (O) }\end{array}$ & $\begin{array}{l}\text { Sample } \\
\text { Mean (M) }\end{array}$ & $\begin{array}{l}\text { Standard } \\
\text { Deviation } \\
\text { (STDEV) }\end{array}$ & $\begin{array}{l}\text { T Statistics } \\
(\mid \mathbf{O} / \text { STDEV } \mid)\end{array}$ & P Values \\
\hline OFC -> DWB & 0.281 & 0.286 & 0.108 & 2.592 & $\mathbf{0 . 0 1 0}$ \\
\hline PGN -> DWB & 0.118 & 0.116 & 0.105 & 1.126 & $\mathbf{0 . 2 6 0}$ \\
\hline SRE -> DWB & 0.345 & 0.347 & 0.144 & 2.402 & $\mathbf{0 . 0 1 6}$ \\
\hline SRE* OFC -> DWB & 0.017 & 0.024 & 0.066 & 0.254 & $\mathbf{0 . 8 0 0}$ \\
\hline SRE*PNG -> DWB & -0.105 & -0.113 & 0.063 & 1.666 & $\mathbf{0 . 0 9 6}$ \\
\hline
\end{tabular}

Source: $\quad$ Smart PLS 3.2.8

\section{Discussion}

The key purpose of this study is to observe that self- regulatory efficacy has moderating effect on the association among organizational formal controls, group norms and deviance activities among teaching staff of the Pakistani universities. Generally, this study successfully understands the key elements of deviant behavior at workplace which provide the answers to the research questions: 
1. To what extent does organizational formal control explain deviant workplace behavior?

2. To what extent does perceive group norms explain deviant workplace behavior?

3. Does self regularity efficacy moderate the relationship between organizational formal control and deviant workplace behavior?

4. Does self regularity efficacy moderate the relationship between perceived group norms and deviant workplace behavior?

Concerning the strong association among external latent variables and internal latent variables, the result of this research shows 5 hypotheses, from which 3 were accepted. The findings from the PLS path model indicate the organizational formal control (IV) have positive and significant association with Deviant Workplace Behavior (DV), Perceived group norms (IV) have no relationship with Deviant workplace behavior (DV), Self regularity efficacy (IV) have positive and significant association with deviant workplace behavior (DV).

Self-regularity efficacy Moderates the association among Organizational formal control (IV) and deviant workplace behavior (DV) the present study found that the SRE didn't moderates the relationship between OFC and DWB. Secondly, Self- regulatory efficacy have moderating effect on the association among perceived group norms (IV) and deviant workplace behavior (DV) this research institute that SRE have positive effect of moderation on the association among organizational formal control and deviant behavior at working place.

The first research question was whether the measurements of organizational formal control explain deviant workplace behavior. This research question in line with, the first determination of the current study was to observe the association among organizational formal controls and DWB. Organizational formal control mentions the mechanisms set in place by organization which includes disciplinary measures, rules and regulations, and auditing with the purpose of detecting, monitoring, punishing and decreasing the happening of inappropriate behavior (Kura, 2014). Two dimensions of organizational control systems (i.e., behavior-based control and outcome-based control) that can influence employee's behavior. As proposed by Y. Ibrahim \& Arshad, (2017)organizational formal control reduces the likelihood of employees to engage in dysfunctional behavior. Hence, this research hypothesized that organizational formal control is significant and positively related to workplace deviance.

The second research question was whether the measurements of perceived group norms explain deviant workplace behavior. This research question in line with, the second determination of this research was to examine the association among perceived group norms and deviant behavior at working place. Group norms refer to established rules that define acceptable and unacceptable behavior in a group (Chernyak-hai, Kim, \& Tziner, 2018). Group norm is one of the factor that have no influence on attitude and behavior of individuals in general. For example, the two dimensions of group norm (i.e., descriptive norms and injunctive norms) have been used to predict adolescent substance use(Kaakinen \& Oksanen, 2018), sexual harassment (Adeoti et al., 2017) and pro-environmental behavior, among others(Q. Iqbal \& Hassan, 2017; Malik \& Younas, 2017; Wang et al., 2018). Descriptive norms refer to group norm that describes the observations of what many others actually do in a given situation, while injunctive norms reflect the perceptions of what most others approve or disapprove (Walsh et al., 2017).Furthermore, prior researches on the effect of perceived group norms with the social learning theory were mainly focused on health associated behaviors (Helle et al., 2018; Kong \& Kim, 2017; Schilpzand, Pater, \& Erez, 2016; Universitesi \& Sezen, 2015) rather than on deviant workplace behaviors. 
The proposed moderating role of self-regularity efficacy on the association among organizational formal control, workgroup norms and deviant behavior at working place because Bandura's selfefficacy theory (1986) and later studies (Carcioppolo et al., 2016; Choi, Ahn, \& Lee, 2015; Dickie et al., 2017) have concluded that all those with a higher sense of self-control are less likely to engage in deviant behavior. Additionally, Bandura, (1999)noted that perceived self-efficacy is an important respect to understand the stages of motivation and then performance happenings because by this individual able to shape the way of think, feel and behave.

Following this argument, the third research question was whether self-regularity efficacy moderates the association among organizational formal control and deviant behavior at working place. This research question in line with, the third purpose of this study was to assess the self-regularity efficacy moderation on the association among organizational formal control and deviant behavior at working place.

Individuals with high self-regularity efficacy were more able to dominate their involuntary tendencies in the direction of deviant behavior at work Mekpor, Dartey-baah, \& Mekpor, (2018), because such employees with high levels of self-regularity efficacy consider positively and are selfindulgent in nature than those with low sense of self regularity efficacy (Olivari, Cuccì, Bonanomi, \& Tagliabue, 2017). Along similar lines, individuals with highest self-regularity efficacy may have been able to internalize their negative emotional state or actions. They were abler to follow organizational instructions and guidelines and find easy to follow. Hence, their regards of organizational instructions and guidelines, make them less likely to conform to formal control started by their organizations, thereby restraining them from engaging in organizational deviance.

From self-efficacy perspective, highest level of self-regularity efficacy enables employees to predict event at work and to develop ways to control those events. Hence, it is estimated that high levels of self-regularity efficacy could negatively energize employees' coping activity when dealing with forces within a work environment including workgroup influence(Liu \& Li, 2016).

Furthermore, self-efficacy theory proposes that employees high in self-regularity efficacy do not exhibit deviant acts even if they faced environmental and situation forces at work (e.g., workgroup influence towards deviant behaviors). Based on the foregoing arguments, the last research question was whether moderation impact of self-regularity efficacy on association among perceived group norms and deviant behavior at working place. The fourth purpose of current research study was to assess the moderation of self-regularity efficacy on the association among organizational formal control and deviant behavior at working place.

Likewise, findings provide support for the view that the self-regularity efficacy moderated the association among perceived descriptive norm and organizational deviant activities. These findings are not surprising because they are consistent with self-efficacy belief (Bandura, 1993, 1999), which suggests that self-regularity efficacy moderated the relationship among perceived descriptive norm and deviant workplace behavior, in such a way that individual with higher level of self-regularity efficacy are not likely to engage in deviant behavior at work regardless of pressure from reference others to do so. More importantly, this result showed that when employees find themselves in under the influence of reference others, self-regularity efficacy help them to attain compliance with significant organizational norms and doing that keep them away from involving in deviant workplace behaviors. Additionally, the results suggest that self-regularity efficacy have a significant part in regulating behaviors and observance to right self-sanctions for flawed behavior. 


\section{Limitations and Future Research Directions}

This current study assumes a non-probability sampling (i.e., quota sampling) in which all components of the target population were not taken, such as the range to which sample size characterizes the complete population cannot be recognized. Hence, future research needs to go outside using quota sampling if sample frame can be attained so that probability sampling technique could be applied. Therefore, one sample frame is attained then the results of the study can be comprehensive to the complete academics in the Pakistani universities.

The current study suggestions quite restricted generalizability as it intensive generally on teaching staff from universities of Pakistan. Consequently, additional work is desirable to contain nonteaching staff from several universities in direction to specify the findings. Universities should be studied and compared with different institutes of higher education such as polytechnics, monotechnics and colleges.

There is no significant moderation impact of self-regularity efficacy on the association among perceived behavior control also interpersonal deviant was found, and self-regularity efficacy was not found moderation on the relationship between perceived descriptive norms and organizational deviance. Possibly some mediating effects could also occur.

\section{Conclusion}

The findings of the current study offer very important theoretical and practical implications in the area of research related to deviant behavior at workplace. Moreover, future research recommendation can be drawn based upon the on limitations of the current research study. Findings from this study provide support to the basic theoretical suggestions. In specific, the present study has effectively answered all of the research questions and objectives even with some of its limitations. This study provides empirical and theoretical support for the moderating effect of self-regularity efficacy on the association among organizational formal control, workgroup norms and deviant workplace behavior. The study has also managed to evaluate how self-regularity efficacy theoretically moderates the relationships between the exogenous and endogenous variables.

\section{References}

Adeoti, M. O., Shamsudin, F. M., \& Wan, C. Y. (2017). Effects of occupational stress and workplace spirituality on workplace deviance in academia Effects of Occupational Stress and Workplace Spirituality on. (September).

Ahad, R., Mustafa, M. Z., Mohamad, S., Abdullah, N. H. S., \& Nordin, M. N. (2021). Work attitude, organizational commitment and emotional intelligence of Malaysian vocational college teachers. Journal of Technical Education and Training, 13(1), 15-21. https://doi.org/10.30880/jtet.2021.13.01.002

Al-Shuaibi, A. S. I., Subramaniam, C., \& Shamsudin, F. M. (2014). The Mediating Influence of Job Satisfaction on the Relationship between HR Practices and Cyberdeviance Ahmad. Journal of Marketing and Management, 5(1), 105-119. https://doi.org/10.1017/CBO9781107415324.004

Ali, R., Khan, M. S., Ghazi, S. R., Shahzad, S., \& Khan, I. (2010). Teachers' Training-A Grey Area in Higher Education. Asian Social Science, 6(7), 43-48.

Babakus, E., Cravens, D. W., Grant, K., Ingram, T. N., \& Laforge, R. W. (1996). Research in Marketing. $13,345-363$.

Baltaru, R. D. (2019). Do non-academic professionals enhance universities' performance? Reputation vs. organisation. Studies in Higher Education, 44(7), 1183-1196. 
https://doi.org/10.1080/03075079.2017.1421156

Bandura, A. (1993). Perceived self efficacy in cognitive development and functioning.

Bandura, A. (1999). Social cognitive theory of personality. 154-196.

Barhight, L. R., Hubbard, J. A., Grassetti, S. N., Morrow, M. T., Barhight, L. R., Hubbard, J. A., ... Morrow, M. T. (2015). Relations Between Actual Group Norms, Perceived Peer Behavior , and Bystander Children's Intervention to Bullying Relations Between Actual Group Norms , Perceived Peer Behavior, and Bystander Children's Intervention to Bullying. 4416(November). https://doi.org/10.1080/15374416.2015.1046180

Bennett, R. J., \& Robinson, S. L. (2000). Development of a Measure of Workplace Deviance. 85(3), 349360 .

Carcioppolo, N., Dunleavy, V. O., Yang, Q., Carcioppolo, N., Orrego, V., \& Yang, Q. (2016). How Do Perceived Descriptive Norms Influence Indoor Tanning Intentions? An Application of the Theory of Normative Social Behavior How Do Perceived Descriptive Norms Influence Indoor Tanning Intentions? An Application of the Theory of Normative Social Be. 0236(June). https://doi.org/10.1080/10410236.2015.1120697

Carre, J. R., Mueller, S. M., Schleicher, K. M., \& Jones, D. N. (2017). Psychopathy And Deviant Workplace Behavior: A Comparison Of Two Psychopathy Models. 1-20.

Chang, T., Chou, S. Y., \& Han, B. (2018). Silent Leaders in the Workplace : Forms of Leadership Silence , Attributions of Leadership Silence, and Accuracy of Attributions. https://doi.org/10.1177/2329488418777041

Chernyak-hai, L., Kim, S., \& Tziner, A. (2018). Relationships Between Workplace Deviance Interacted With Gender and Marital Status: The Correspondence Analysis Approach. https://doi.org/10.1177/0033294118783500

Choi, B., Ahn, S., \& Lee, S. (2015). Construction Workers ' Group Norms and Personal Standards Regarding Safety Behavior: Social Identity Theory Perspective. 1-11. https://doi.org/10.1061/(ASCE)ME.1943-5479.0000511.

Côté, K., Lauzier, M., \& Stinglhamber, F. (2021). The relationship between presenteeism and job satisfaction: A mediated moderation model using work engagement and perceived organizational support. European Management Journal, 39(2), 270-278. https://doi.org/10.1016/j.emj.2020.09.001

Dickie, R., Rasmussen, S., Cain, R., Williams, L., Dickie, R., Rasmussen, S., ... Williams, L. (2017). The effects of perceived social norms on handwashing behaviour in students. Psychology, Health \& Medicine, 8506(June), o. https://doi.org/10.1080/13548506.2017.1338736

Dwyer, S., Mesak, H., \& Hsu, M. (2005). An Exploratory Examination of the Influence of National Culture on Cross-National Product Diffusion. Journal of International Marketing, 13(2), 1-27. https://doi.org/10.1509/jimk.13.2.1.64859

Fagbohungbe, B. O., Akinbode, G. a., \& Ayodeji, F. (2012). Organizational Determinants of Workplace Deviant Behaviours: An Empirical Analysis in Nigeria. International Journal of Business and Management, 7(5), 207-221. https://doi.org/10.5539/ijbm.v7n5p207

Falomir-pichastor, J. M., Mugny, G., \& Berent, J. (2015). The side effect of egalitarian norms : Reactive group distinctiveness , biological essentialism, and sexual prejudice. https://doi.org/10.1177/1368430215613843

Farida, N., Ardyan, E., \& Nuryakin, N. (2016). Gender differences in interest in using electronic money: An application of theory planned behavior. International Review of Management and Marketing, 6(4), 898-903.

Fox, S., Spector, P. E., Goh, A., Bruursema, K., \& Kessler, S. R. (2012). The deviant citizen: Measuring potential positive relations between counterproductive work behaviour and organizational citizenship behaviour. Journal of Occupational and Organizational Psychology, 85(1), 199-220. 
https://doi.org/10.1111/j.2044-8325.2011.02032.X

Fox, S., Spector, P. E., \& Miles, D. (2001). Counterproductive Work Behavior (CWB) in Response to Job Stressors and Organizational Justice: Some Mediator and Moderator Tests for Autonomy and Emotions. Journal of Vocational Behavior, 59(3), 291-309. https://doi.org/10.1006/jvbe.2001.1803

Golparvar, M. (2015). Unconventional Functions of Deviant Behaviors in the Relationship Between Job Stress and Emotional Exhaustion: Three Study Findings. https://doi.org/10.1007/s12144-0149292-8

Guan, Y., Zhou, W., Ye, L., Jiang, P., \& Zhou, Y. (2015). Perceived organizational career management and career adaptability as predictors of success and turnover intention among Chinese employees. Journal of Vocational Behavior, 88, 230-237. https://doi.org/10.1016/j.jvb.2015.04.002

Harisur, M., Howladar, R., Rahman, S., \& Uddin, A. (2018). Deviant Workplace Behavior and Job Performance: The Moderating Effect of Transformational Leadership. 11(1). https://doi.org/10.22059/ijms.2018.226143.672514

Helle, A. C., Deshong, H. L., Lengel, G. J., Meyer, N. A., Butler, J., \& Mullins-sweatt, S. N. (2018). Personality and Individual Di ff erences Utilizing Five Factor Model facets to conceptualize counterproductive, unethical, and organizational citizenship workplace behaviors $i$. Personality and Individual Differences, 135(June), 120. https://doi.org/10.1016/j.paid.2018.06.056

Ibrahim, Y., \& Arshad, I. (2017). Examining the impact of product involvement, subjective norm and perceived behavioral control on investment intentions of individual investors in Pakistan. Investment Management and Financial Innovations, 14(4), 181-193. https://doi.org/10.21511/imfi.14(4).2017.15

Iqbal, A., Rehman, K., Ali, A., Khan, I., \& Khan, F. A. (2014). Critical Analysis of the Problems of Education in Pakistan: Possible Solutions. International Journal of Evaluation and Research in Education, 3(2), 79-84. https://doi.org/2252-8822

Iqbal, Q., \& Hassan, S. H. (2017). Role of Workplace Spirituality: Personality Traits and Counterproductive Workplace Behaviors in Banking Sector. (January 2019).

Kaakinen, M., \& Oksanen, A. (2018). Computers in Human Behavior Did the risk of exposure to online hate increase after the November 2015 Paris attacks? A group relations approach. 78, 90-97. https://doi.org/10.1016/j.chb.2017.09.022

Khattak, M. N., Khan, M. B., Fatima, T., Zul, S., \& Shah, A. (2018). Asia Paci fi c Management Review The underlying mechanism between perceived organizational injustice and deviant workplace behaviors: Moderating role of personality traits. 1-11. https://doi.org/10.1016/j.apmrv.2018.05.001

Kong, H., \& Kim, H. (2017). Customer Aggression and Workplace Deviance: The Moderating Role Of Psychological Ownership. 45(11), 1761-1773.

Kumi, E. (2013). Are Demographic Variables Predictors of Work Deviant Behavior? International Journal of Management Sciences, 1(1), 1-10.

Kura, K. M. (2014). Organisational formal controls, group norms and workplace deviance: The moderating role of self-regulatory efficacy. I, (August), 306.

Kura, K. M., Faridahwati, M. S., \& Chauhan, A. (2014). Influence of organisational formal control, group norms, self-regulatory efficacy on workplace deviance in the Nigerian universities: Data screening and preliminary analysis. 7th National Human Resource Management Conference, 19. Kedah D.A. Malaysia-o6o10: SBM_Universiti Utara Malaysia.

Liu, C., \& Li, H. (2016). Stressors and Stressor Appraisals: the Moderating Effect of Task Efficacy. Journal of Business and Psychology. https://doi.org/10.1007/s10869-016-9483-4

Malik, M. S., \& Younas, S. (2017). The Workplace Deviance Perspective of Employee Responses to 
Workplace Bullying: The Moderating Effect of Toxic Leadership and Mediating Effect of Emotional Exhaustion. 8(1), 33-50.

Mehar, M. R., Asif, M., \& Hassan, A. (2018). Edelweiss Psychiatry Open Access Impact of Workplace Deviance Behaviors on Turnover Intention of Employees in Pakistan. 1(1), 44-49.

Mekpor, B., Dartey-baah, K., \& Mekpor, B. (2018). Voluntary workplace behaviors among employees of high and A comparative study of selected banks in Kwasi Dartey-Baah. https://doi.org/10.1108/IJOA-o6-2017-1179

Mohamed, H. A., Zeinhom, M., Higazee, A., \& Goda, S. (2018). Organizational Justice and Workplace Bullying: The Experience of Nurses. 6(4), 208-213. https://doi.org/10.12691/ajnr-6-4-9

Murphy, S. E. (2017). Conceptual Framework on Workplace Deviance Behaviour: A Review. https://doi.org/10.1177/0971685817713284

Nasurdin, A. M., Ahmad, N. H., \& Razalli, A. A. (2014). POLITICS , JUSTICE , STRESS , AND DEVIANT BEHAVIOUR IN ORGANIZATIONS : International Journal of Business and Society, 15(2), 235254 .

Nelofer, H. (2013). Quality of private universities in Pakistan: an analysis of higher education commission rankings 2012. International Journal of Educational Management, 27(7), 775-786.

Noe, R. a., Tews, M. J., \& Marand, A. D. (2013). Individual differences and informal learning in the workplace. Journal of Vocational Behavior, 83(3), 327-335. https://doi.org/10.1016/j.jvb.2013.06.009

Olivari, M. G., Cuccì, G., Bonanomi, A., \& Tagliabue, S. (2017). Retrospective Paternal and Maternal Parenting Styles, Regulatory Self-Efficacy and Adolescent Risk Taking. Marriage \& Family Review, o(o), 1-14. https://doi.org/10.1080/01494929.2017.1403990

Oliver, R. L., Anderson, E., Oliver, L., \& Anderson, E. (2015). Test of the Empirical of BehaviorConsequences Control Systems. 58(4), 53-67.

Quaisar, I. K., Khulida, K. Y., \& Tan, F. (2014). The Effect of Human Capital, Reward System and Career Commitment on Career Success: Mediating Role of Counterproductive Work Behaviour in Higher Education Sector of Pakistan. 7th National Human Resource Management Conference, 14-19.

Quaisar, I. K., Shukor, D. A. S., \& Soffian, D. S. S. I. (2015). The influence of career planning and HRM practices on career success of faculty members in public sector universities of Pakistan. Journal of Resources Developement and Management, 9, 68-75.

Quaisar, I. K., Shukor, D. A. S., \& Soffian, D. S. S. I. (2016a). Career Success and Organizational Justice as the Potential Predictors of Perceived University Performance: A Study from Public Sector Universities of Pakistan. European Journal of Business and Management, 8(16), 131-139.

Quaisar, I. K., Shukor, D. A. S., \& Soffian, D. S. S. I. (2016b). The mediatingeEffect of career success on HRM practices and university Performance: A study from public sector universities of Pakistan. Current Economics and Management Research, 2(1), 1-8.

Quddus, A., Nugroho, B. S., Hakim, L., Ritaudin, M. S., Nurhasanah, E., Suarsa, A., ... Sudargini, Y. (2020). Effect of ecological, servant dan digital leadership style influence university performance? evidence from indonesian universities. Systematic Reviews in Pharmacy, 11(10), 408-417. https://doi.org/10.31838/srp.2020.10.64

Rabiul, M. K., \& Yean, T. F. (2021). Leadership styles, motivating language, and work engagement: An empirical investigation of the hotel industry. International Journal of Hospitality Management, 92(September 2020), 102712. https://doi.org/10.1016/j.ijhm.2020.102712

Ramzy, O., Bedawy, R. El, \& Maher, A. (2018). Dysfunctional Behavior at the Workplace and Its Impact on Employees ' Job Dysfunctional Behavior at the Workplace and Its Impact on Employees ' Job Performance. (July). https://doi.org/10.5430/ijba.v9n4p224

Robinson, S. L., \& Bennett, R. J. (1995). A TYPOLOGY OF DEVIANT WORKPLACE BEHAVIORS : A 
MULTIDIMENSIONAL SCALING STUDY. Academy of Management Journal, 38(2), 555-572.

Saeed, R. D., Mizna, Lodhi, R. N., Gill, A. A., Anam, A., Simra, \& Amber, Iqbal. (2014). Impact of Human Resource Practices on Deviant Workplace Behavior A Study on Banking Sector Employees. Journal of Basic and Applied Scientific Rerearch, 4(2), 81-86.

Saher, N., Bibi, S., Farmanullah, S., \& Abbas, S. (2014). Career Success in Pakistan: Human Capital and Social Networking. Middle East Journal of Scientific Research, 19(2), 163-171. https://doi.org/10.5829/idosi.mejsr.2014.19.2.2203

Sang, L. C., Xuan, S. S., Ismail, W. K. wan, Siti, Z. A. R., \& Tan, K. O. (2014). An Analysis on Academicians Job Satisfaction in the Perspective of HRD Practices. International Education Studies, 7(7), 85-95. https://doi.org/10.5539/ies.v7n7p85

Schilpzand, P., Pater, I. E. De, \& Erez, A. (2016). Workplace incivility: A review of the literature and agenda for future research. (October). https://doi.org/10.1002/job.1976

Shabbir, M., Khalid, M. I., Dogar, A. H., Amin, M., Saleem, K., Masood, S., \& Tatlah, I. A. (2014). Problems and Issues in Relation to Quality Assurance Practices in Higher Education: Views of Students, Teachers and Heads of Quality Enhancement Cells ( QEC's ). International Journal of AYER, 4, 116-122. Retrieved from http://www.ayeronline.com

Spector, P. E. (2010). The relationship of personality to counterproductive work behavior (CWB): An integration of perspectives. Human Resource Management Review, 21(4), 342-352. https://doi.org/10.1016/j.hrmr.2010.10.002

Spector, P. E., \& Fox, S. (2010). Theorizing about the deviant citizen: An attributional explanation of the interplay of organizational citizenship and counterproductive work behavior. Human Resource Management Review, 20(2), 132-143. https://doi.org/10.1016/j.hrmr.2009.06.oo2

Stewart, S. M., Bing, M. N., Davison, H. K., Woehr, D. J., \& Mcintyre, M. D. (2014). In the Eyes of the Beholder: A Non-Self-Report Measure of Workplace In the Eyes of the Beholder: A Non-SelfReport Measure of Workplace Deviance. (June). https://doi.org/10.1037/ao012605

Sunday, A. J. (2013). Work Place Deviant Behaviour: A Case Study of Intels Nigeria Limited. Research on Humanities and Social Sciences, 3(22), 49-57.

Tuna, M., Ghazzawi, I., Yesiltas, M., Akbas, A., Siddik, T., Tuna, M., ... Siddik, T. (2016). The effects of the perceived external prestige of the organization on employee deviant workplace behavior The mediating role of job satisfaction.

Universitesi, I. M., \& Sezen, B. (2015). Determinants of Constructive Deviance: The Mediator Role of Psychological Determinants of Constructive Deviance: The Mediator Role of Psychological Ownership. (January 2016). https://doi.org/10.5539/ibr.v8n4p107

Walsh, B. M., Lee, J. J., Jensen, J. M., Mcgonagle, A. K., Samnani, A., \& Walsh, B. M. (2017). Positive Leader Behaviors and Workplace Incivility: the Mediating Role of Perceived Norms for Respect. https://doi.org/10.1007/s10869-017-9505-X

Wang, S. P., Chen, M. S., \& Li, M. J. (2018). Key factors affecting deviant workplace behavior. 12(10), 258-266. https://doi.org/10.5897/AJBM2018.8491

Zimmerman, B. J., Bandura, A., \& Martinez-Pons, M. (1992). Self-motivation for academic attainment: The role of self-efficacy beliefs and personal goal setting. American Educational Research Journal, 29(3), 663-676. https://doi.org/10.1016/Soo9o-2616(03)ooo28-7

Zimmerman, B. J., Bandura, A., Martinez-pons, M., \& Martinez-pons, M. (1992). American Educational Research Journal. https://doi.org/10.3102/o0028312029003663 